\title{
Analysis of renin-angiotensin aldosterone system gene polymorphisms in malaysian essential hypertensive and type 2 diabetic subjects
}

\author{
Vasudevan Ramachandran ${ }^{1}$, Patimah Ismail ${ }^{* 1}$, Johnson Stanslas ${ }^{1}$ and \\ Norashikin Shamsudin ${ }^{2}$
}

Address: ${ }^{1}$ Genetic Research Group, Department of Biomedical Science, Faculty of Medicine and Health Sciences, Universiti Putra Malaysia, Selangor, Malaysia and ${ }^{2}$ Department of Medicine, Faculty of Medicine and Health Sciences, Universiti Putra Malaysia, Selangor, Malaysia

Email: Vasudevan Ramachandran - vasuphd@gmail.com; Patimah Ismail* - patimah@medic.upm.edu.my;

Johnson Stanslas - rcxjs@medic.upm.edu.my; Norashikin Shamsudin - aliffarhan@yahoo.com

* Corresponding author

Published: 25 February 2009

Cardiovascular Diabetology 2009, 8:1 I doi:10.1 186/1475-2840-8-1 I

This article is available from: http://www.cardiab.com/content/8/I/II

(c) 2009 Ramachandran et al; licensee BioMed Central Ltd.

This is an Open Access article distributed under the terms of the Creative Commons Attribution License (http://creativecommons.org/licenses/by/2.0), which permits unrestricted use, distribution, and reproduction in any medium, provided the original work is properly cited.

\begin{abstract}
Background: The renin-angiotensin aldosterone system (RAAS) plays an important role in regulating the blood pressure and the genetic polymorphisms of RAAS genes has been extensively studied in relation to the cardiovascular diseases in various populations with conflicting results. The aim of this study was to determine the association of five genetic polymorphisms (A6G and A20C of angiotensinogen (AGT), Mbol of renin, Gly460Trp of aldosterone synthase and Lys I73Arg of adducin) of RAAS genes in Malaysian essential hypertensive and type 2 diabetic subjects.
\end{abstract}

Methods: RAAS gene polymorphisms were determined using mutagenically separated PCR and PCR-RFLP method in a total of 270 subjects consisting of 70 hypertensive subjects without type 2 diabetes mellitus (T2DM), 60 T2DM, 65 hypertensive subjects with T2DM and 75 control subjects.

Results: There was significant difference found in age, body mass index, systolic/diastolic blood pressure, fasting plasma glucose and high density lipoprotein cholesterol levels between the hypertensive subjects with or without T2DM and control subjects. No statistically significant differences between groups were found in the allele frequency and genotype distribution for A20C variant of AGT gene, Mbol of renin, Gly460Trp of aldosterone and Lys I 73Arg of adducin ( $p>0.05)$. However, the results for A6G of AGT gene revealed significant differences in allele and genotype frequencies in essential hypertension with or without T2DM $(p<0.00 \mathrm{I})$.

Conclusion: Among the five polymorphisms of RAAS genes only A6G variant of AGT gene was significantly associated in Malaysian essential hypertensive and type 2 diabetic subjects. Therefore, A6G polymorphism of the AGT gene could be a potential genetic marker for increased susceptibility to essential hypertension with or without T2DMin Malaysian subjects. 


\section{Background}

It is well known that the renin angiotensin-aldosterone system (RAAS) as a circulating or hormonal system that regulates blood pressure, electrolyte and fluid homeostasis [1]. The development of hypertension in diabetes is also due to the effects of RAAS activation [2]. On the basis of biochemical or physiological functions, genetic variants of angiotensin converting enzyme, angiotensinogen (AGT), angiotensin type 1 receptor, aldosterone synthase (CYP11B2), adducin, renin of RAAS have been intensively studied in various populations with conflicting results in relation to hypertension [3], diabetic complications [4], coronary heart disease [5] and renal disease [6].

After an initial report [7], several studies analyzed the association of AGT variants in relation to hypertension [8] and diabetes [9] with conflicting results. Among the variants of AGT gene, A-20C variant (adenine-to-cytosine transition at nucleotide -20) of the 5' upstream core promoter region affects the transcription activity of AGT mRNA and thereby alters the plasma AGT level and possibly involved in the development of EHT [10]. Another variant A for G substitution at position - 6 in the core promoter of the gene has been significantly associated with elevated plasma AGT levels, AGT gene transcription and EHT [11].

Renin plays a crucial role in the regulation of blood pressure, and the renin gene (REN) is considered as a good candidate quantitative trait locus involved in the etiology of essential hypertension. The variations in the amount of linkage disequilibrium have been observed at the human $R E N$ gene locus indicating the importance of investigating several REN gene polymorphisms. REN MboI two-allele polymorphism of REN gene shows a positive association with susceptibility to EHT $[12,13]$ and also negative associations [14].

Aldosterone plays an important role in controlling the sodium balance, intravascular volume and in regulating the blood pressure [15]. Aldosterone is synthesized from deoxycorticosterone in the zona golmerulosa of adrenal cortex by a mitochondrial cytochrome P450 enzyme, CYP11B2 [16]. Mutations in CYP11B2 can lead to important changes to arterial pressure and could be responsible for hypertension. The haplotypes in CYP11B2 is strongly associated with hypertension or plasma aldosterone concentrations [17]. An amino acid polymorphism showing Lys173 rather than Arg173 in CYP11B2 gene has been associated with low-renin hypertension in Japanese populations [18].

Adducin is a heteromeric cytoskeleton protein composed of $\alpha$ and $\beta$-subunits was the rate-limiting factor in RAAS, . Variation in the $\alpha$-adducin (ADD1) protein may affect ion transport through modification of actin cytoskeleton assembly and modulation of sodium pump activity [19] and it has been suggested that defects in transport mechanisms may be the cause of hypertension. Several studies have suggested that the association or linkage of G- to-T substitution polymorphism of amino acid residue 460 at nucleotide position 614 of exon 10 of the $\alpha$-Adducin gene in EHT with controversial results in different populations [20].

Hypertension is an extremely common co-morbidity of diabetes and affects $70 \%$ of patients with diabetes and is approximately twice as common in persons with diabetes as in those without diabetes [21]. Several epidemiologic studies show that the evidence for co-existence of hypertension and diabetes is due to common genetic and environmental factors such as diet, physical activity and age interact with the genetic predisposition, leading to the development of cardiovascular disease [22]. The pathogenesis of hypertension in diabetes is complex and involves several unified factors that collectively increase the susceptibility to develop hypertension. There is a strong association between up-regulation of RAAS, hypertension and diabetes [2]. A short-term moderate hyperglycemia has been linked to an increase in plasma renin activity, mean arterial pressure and renal vascular resistance with activation of circulating and the local RAAS [23]. RAAS genes are responsible for excess Angioyensin II production or availability are possible candidates for development of diabetic complications and the RAAS gene polymorphisms has been extensively studied in various populations in relation to diabetic complications [24].

The screening of candidate genes for nucleotide variants that are associated with EHT and T2DM is a core component of much diabetes and hypertension genetics research. Several studies of the genetics of EHT and T2DM have been analysed to select the candidate genes because of known or presumed biological or physiological functions. The choice of candidates is inevitably limited by our incomplete understanding of the regulation of the processes and the pathophysiology of EHT and T2DM. Moreover there was no gene consistently associated with or linked to EHT and T2DM $[25,4]$.

The present study was undertaken to determine the possible association of two genetic variants of AGT gene and one polymorphism from each of these candidate genes; $R E N$, CYP11B2 and ADD1 in Malaysian EHT with or without T2DM and T2DM subjects.

\section{Methods \\ Study subjects}

A total of 195 patients were recruited from Universiti Putra Malaysia (UPM) Physician Clinic, Hospital Kuala Lumpur. Unrelated healthy individuals were collected 
randomly (no age-sex matched controls) from UPM staff members and volunteers. The subjects were divided into four main groups: EHT without T2DM (group 1, No-70), T2DM (group 2, No-60) EHT with T2DM (group 3, No$65)$ and control subjects as group 4 (No-75). A questionnaire in both Malay and English languages were obtained to asses the socio-demographic factors. Informed consent was obtained from all the subjects who have participated in this study. The protocol of this study was approved by the Ethical Committee of the Faculty of Medical and Health Sciences, Universiti Putra Malaysia (UPM/FPSK/ PADS/T-TAD/T7-MJKEtikaPPer/F01).

\section{Physical measurements}

Individual weight and heights were obtained to calculate body mass index (BMI) using the formula, weight $(\mathrm{kg}) /$ [height (m2)]. Hypertension was defined as $\geq 140 \mathrm{mmHg}$ of systolic blood pressure (SBP) and $\geq 90 \mathrm{mmHg}$ of diastolic blood pressure (DBP) or who were receiving anti-hypertensive therapy. The blood pressure was measured on the right arm of the subjects using an automated blood pressure monitor (Omron, Japan) by seated and rested for 5 minutes. The fasting blood glucose levels were obtained from the medical records of all the known diabetic subjects. For control subjects, fasting blood glucose level was measured using MediSense Precision-G blood glucose monitor.

\section{DNA preparation}

Four-five milliliters of blood samples were collected from the peripheral venous blood into an EDTA tube (Becton Dickinson, NJ) by a qualified phlebotomist. Genomic DNA extraction was carried out using the DNA isolation kit (BioBasic.Inc, Canada). The purity of extracted DNA was quantified using Eppendorf UVette ${ }^{\circledast}$ in Biophotometer (Eppendorf, Hamburg, Germany).

\section{Biochemical analysis}

Before the DNA extraction, serum was separated from the blood by centrifuge at $4000 \mathrm{rpm}$ and stored at $-20^{\circ} \mathrm{C}$ until further analysis. Serum levels of high-density lipoproteincholesterol (HDL-C), total cholesterol (TC) and triglycerides (TG) were measured enzymatically on a Hitachi-912 Autoanalyser (Mannheim, Germany) with kits supplied by Roche Diagnostics (Mannheim, Germany). Low density lipoprotein cholesterol (LDL-C) was calculated using Friedewald formula [26].

\section{Determination of RAAS gene polymorphisms}

Detection of A6G polymorphism of AGT gene and Gly460Trp polymorphism of ADD1 was performed by mutagenically separated PCR (MS-PCR) technique [27] with both normal and mutant alleles were added together in one reaction tube. The other polymorphisms (A20C, MboI and Lys173Arg) were assayed by restriction analysis of the PCR product with the respective restriction enzymes.

The A6G polymorphism of AGT gene was amplified in a $25-\mu \mathrm{L}$ reaction mixture contains the template DNA, 10 $\mathrm{pmol} / \mathrm{L}$ of each three primers, $0.4 \mathrm{mmol} / \mathrm{L}$ each dNTP, 2 $\mathrm{mmol} / \mathrm{L} \mathrm{MgCl}_{2}, 1 \times$ Taq buffer and 1 unit of NEB Taq DNA polymerase (New England Biolabs, Beverly, MA, USA). The temperature for initial denaturation step was $94^{\circ} \mathrm{C}$ for $5 \mathrm{~min}$, followed by 35 number of cycles, each of $94^{\circ} \mathrm{C}$ for 45 seconds (s), $62^{\circ} \mathrm{C}$ for $45 \mathrm{~s}$, and $72^{\circ} \mathrm{C}$ for $45 \mathrm{~s}$, and by a final extension at $72^{\circ} \mathrm{C}$ for $7 \mathrm{~min}$. The amplification reaction yields a 187 -bp and a 207-bp product for the A- 6 and G-6 alleles respectively [28].

PCR amplification was performed for Gly460Trp polymorphism of ADD1 gene in a $25-\mu \mathrm{L}$ reaction mixture contained $2.4 \mathrm{pmol} / \mathrm{L}$ of forward primer (FP)-1, $4.8 \mathrm{pmol} / \mathrm{L}$ of FP-2 and $6 \mathrm{pmol} / \mathrm{L}$ of reverse primer (RP), $0.4 \mathrm{mmol} / \mathrm{L}$ each dNTP, $2 \mathrm{mmol} / \mathrm{L} \mathrm{MgCl}_{2}$, $1 \times$ Taq buffer and 1 unit of NEB Taq DNA polymerase (New England Biolabs, Beverly, MA, USA) and the template DNA. The initial denaturation was set up for 3 minutes at $95^{\circ} \mathrm{C}$ followed by 35 cycles of denaturation for $20 \mathrm{~s}$ at $94^{\circ} \mathrm{C}$, annealing for $30 \mathrm{~s}$ at $60^{\circ} \mathrm{C}$, and extension for $30 \mathrm{~s}$ at $72^{\circ} \mathrm{C}$ [29-31]. The size of the PCR products was $220 \mathrm{bp}$ and $234 \mathrm{bp}$ for the 460Gly and 460Trp alleles, respectively.

To determine the genotypes of MboI of REN, Gly460Trp of CYP11B2 and Lys173Arg of ADD1 genes, genomic DNA was amplified first by the respective primers (Table 1) using polymerase chain reaction (PCR) technnique. The PCR amplification for all the respective polymorphisms was performed in total volume of $25-\mu \mathrm{L}$ reaction mixture consisting of $10 \mathrm{pmol}$ of each primer, $0.3-0.4 \mathrm{mmol} / \mathrm{L}$ each dNTP, $1.5-3.0 \mathrm{mmol} / \mathrm{L} \mathrm{MgCl}_{2}, 1 \times$ Taq buffer and 1 unit of NEB Taq DNA polymerase. The PCR products of the respective primers was digested with 2-4 units of the respective restriction enzymes (New England Biolabs, Beverly, MA, USA) and incubated at $37^{\circ} \mathrm{C}$ for 3-5 hours with the respective NEB buffers in a final volume of $20 \mu \mathrm{L}$ reaction mixture. The heat inactivation was done on the basis of manufacture's protocol for the respective restriction enzymes. A negative control containing no genomic DNA and a positive control of known genotype were always included in the set of reactions. All the PCR cycling conditions were carried out on iCycler machine (BioRad Laboratories, Hercules, California, USA). The amplified PCR products for A6G and Gly460Trp polymorphisms were separated on a 3\% Metaphor agarose gel (Cambrex, East Rutherford, NJ, USA), while other polymorphisms were separated at $2-4 \%$ of agarose gel (Bioline, London, UK) and performed in Origins electrophoresis tank (Elchrom Scientific AG, Switzerland). The agarose gel was stained in ethidium bromide and visualized using Alpha 
Table I: Oligonucleotides for amplification and screening for three polymorphisms using PCR-RFLP method

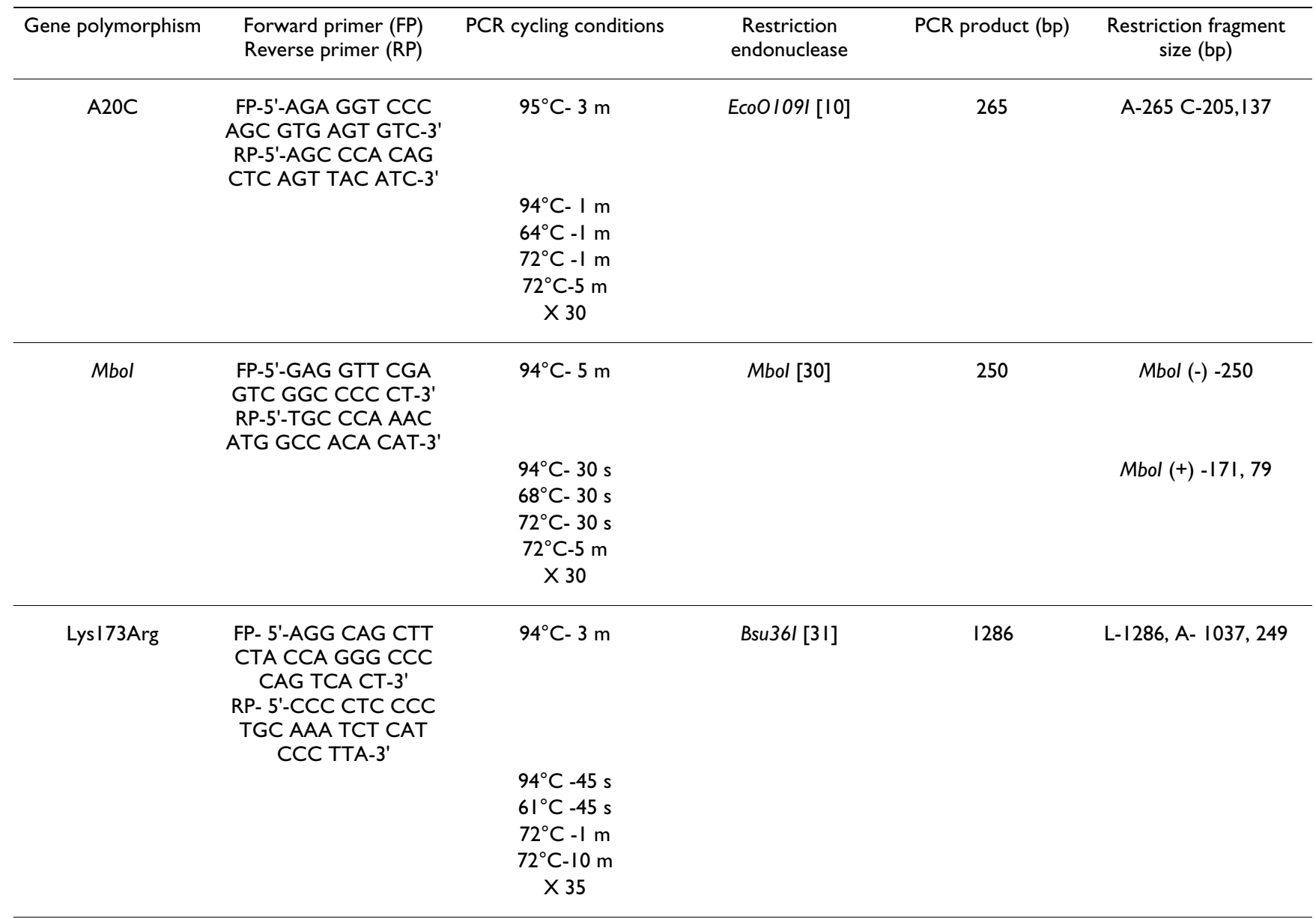

PCR cycling conditions are represented as temperature and time [minute $(\mathrm{m})$, seconds $(\mathrm{s}$ ] of initial denaturation, denaturation, annealing, extension and final extension $X$ number of cycles.

Imager (Alpha Innotech, San Leandro, CA). Table 1 shows the primers used for RFLP method, PCR cycling conditions, restriction endonucleases and the digested restricted fragment size products. Identical results were obtained when genotyping was performed for $10 \%$ of the samples on two separate occasions.

\section{Statistical analysis}

All the statistical analysis was carried out by using SPSS (Chicago, IL) software version 14.0 for Microsoft Windows. Continuous variables were compared between the groups by using two-tailed student's $t$ test. Allelic frequencies were calculated by gene-counting method and the genotype distribution with Hardy-Weinberg expectations by a chi-squared test. Odds ratios (OR) with 95\% confidence intervals (CI) were estimated for the effects of high risk alleles. A level of $P<0.05$ was considered statistically significant.

\section{Results and discussion}

In detecting the association between the genetic polymorphisms and trait using association studies remains controversial. However, it is an efficient method to evaluate the associations of allele frequency or genotype frequencies of candidate genes with diseases to understand the genetic etiology of complex human traits [32]. Taking this into an account, in this present study we determined the possible association of genetic polymorphisms of RAAS genes with EHT and T2DM in Malaysian subjects. To our knowledge, few papers have been published in relation to RAAS gene polymorphisms in Malaysian subjects. Probably this is the first comprehensive reports on RAAS pathway gene polymorphisms in relation to EHT and T2DM in Malaysian subjects.

\section{Baseline characteristics}

A total of 270 subjects were recruited in this study. Among the subjects, 70 (25.93\%) were hypertensive, 60 (22.22\%) 
T2DM, 65 (24.07\%) were hypertensive with T2DM and $75(27.78 \%)$ unrelated healthy individuals. The majority of the subjects in this study were males [163 (60.37\%)] compared to female subjects $[107$ (39.63\%)]. Table 2 summarizes the clinical parameters of all the subjects. According to American Diabetes Association, age plays a significant role in the risk of developing T2DM and it is most often seen in older adults. In this study, the median age in the patient group was 57.21 years and the range was 31-84 years as compared to control group (median 45.37 years, range 30-74). Since the control group is younger than the patient group, there was significant differences found in age in all the three groups as compared with control group ( $\mathrm{p}<0.05)$. This is similar to a study done in Malaysian hypertensive subjects [33] which shows that, the hypertensive subjects ranged from 30 to 78 years old, with a mean age of 54.7 years, while the normotensives ranged from 25 to 78 years old, with a mean 49.3 years, but, in contrast to the findings in Malays [34].

The subjects were stratified according to gender in hypertensive subjects [51 (72.86\%) males and $19(27.14 \%)$ females], T2DM [33 (55\%) males and 27 (45\%) females], T2DM with EHT [40 (61.54\%) males and 25 (38.46\%) females] and unrelated healthy individuals as controls [39 (52.00\%) males and $36(48.00 \%)$ females]. There was a significant difference found in hypertensive subjects as compared to normotensive subjects for gender which was not similar to the prevalence of hypertension found in Malaysian population [35]. The study shows [35] that the prevalence of hypertension in males and females was not significantly different above the age of 40 years, however, aged 15-39 years, hypertension was significantly more prevalent in males than females $(\mathrm{P}<0.05)$ in Malaysian population. Significant differences $(\mathrm{p}<0.05)$ was observed in age, BMI, DBP, FPG, HDL-C and $\mathrm{Na}$ in the patient groups as compared to the control subjects. In hypertensive subjects with or without T2DM, SBP, DBP, BMI, FPG and Na was in higher levels while HDL-C was lower in levels as compared to control subjects and significantly differed than those in controls. The variables of SBP and DBP at the time of participation were significantly higher in hypertensive groups than control group ( $\mathrm{p}<0.001)$. The results, support the previous hypothesis that the higher the blood pressure, the greater the risk of heart attack, heart failure, stroke and kidney disease [36]. The presence of additional risk factors such as BMI and high cholesterol levels increases the CVD risk from hypertension [36]. However, other risk factors such as TC, high LDL-C and low potassium were not significantly different with control subjects. Among the patient groups, obesity was clearly observed in T2DM $(27.89 \pm 3.93)$ as compared to other subjects. However, in hypertensive subjects with or without T2DM were under pre-obesity category $25.63 \pm$ 4.15 and $26.71 \pm 3.59$ respectively as compared to overweight control subjects $(23.91 \pm 4.01)$. The BMI for the

Table 2: Baseline characteristics of the subjects

\begin{tabular}{|c|c|c|c|c|}
\hline Parameters & $\begin{array}{c}\text { Group I } \\
(\mathrm{n}-70)\end{array}$ & $\begin{array}{c}\text { Group } 2 \\
(n-60)\end{array}$ & $\begin{array}{c}\text { Group } 3 \\
(n-65)\end{array}$ & $\begin{array}{c}\text { Group } 4 \\
(n-75)\end{array}$ \\
\hline $\begin{array}{c}\text { Gender } \\
\text { (male/female) }\end{array}$ & $51 / 19 *$ & $33 / 27$ & $40 / 25$ & $39 / 36$ \\
\hline $\begin{array}{c}\text { Age } \\
\text { (Years) }\end{array}$ & $57.70 \pm 11.02 *$ & $57.70 \pm 10.24 *$ & $57.61 \pm 9.76 *$ & $45.37 \pm 10.69$ \\
\hline $\begin{array}{c}\text { BMI } \\
(\mathrm{kg} / \mathrm{m} 2)\end{array}$ & $25.63 \pm 4.15 *$ & $27.89 \pm 3.93 *$ & $26.71 \pm 3.59 *$ & $23.91 \pm 4.01$ \\
\hline $\begin{array}{c}\text { SBP } \\
(\mathrm{mm} \mathrm{Hg})\end{array}$ & $159.44 \pm 17.10 *$ & $125.93 \pm 9.05$ & $|60.26 \pm| 9.01 *$ & $|25.98 \pm 8.8|$ \\
\hline $\begin{array}{c}\mathrm{DBP} \\
(\mathrm{mm} \mathrm{Hg})\end{array}$ & $96.40 \pm 6.52 *$ & $74.97 \pm 7.34$ & $93.60 \pm 3.77^{*}$ & $77.83 \pm 7.09$ \\
\hline $\begin{array}{c}\mathrm{FPG} \\
(\mathrm{mmol} / \mathrm{L})\end{array}$ & $5.24 \pm 0.54 *$ & $\mid \mathrm{I} .85 \pm 4.8 \mathrm{I}^{*}$ & $|1.68 \pm 4.7| *$ & $4.60 \pm 0.91$ \\
\hline $\begin{array}{l}\text { HDL-C } \\
(\mathrm{mmol} / \mathrm{L})\end{array}$ & $0.86 \pm 0.31 *$ & $0.73 \pm 0.22 *$ & $0.78 \pm 0.29 *$ & $1.11 \pm 0.40$ \\
\hline $\begin{array}{l}\text { LDL-C } \\
(\mathrm{mmol} / \mathrm{L})\end{array}$ & $3.42 \pm 1.09$ & $4.04 \pm 1.47 *$ & $3.76 \pm 1.19$ & $3.36 \pm 1.16$ \\
\hline $\begin{array}{c}\mathrm{TG} \\
(\mathrm{mmol} / \mathrm{L}))\end{array}$ & $1.97 \pm 0.99$ & $2.09 \pm 1.01 *$ & $1.95 \pm 0.87$ & $1.64 \pm 0.98$ \\
\hline $\begin{array}{c}\mathrm{TC} \\
(\mathrm{mmol} / \mathrm{L}\end{array}$ & $4.80 \pm 1.10$ & $5.14 \pm 1.31$ & $5.05 \pm 1.26$ & $5.12 \pm 1.38$ \\
\hline $\begin{array}{c}\mathrm{Na} \\
(\mathrm{mEq} / \mathrm{L})\end{array}$ & $144.17 \pm 12.78 *$ & $|33.0| \pm 9.60 *$ & $137.12 \pm 10.11 *$ & $114.73 \pm 18.38$ \\
\hline $\begin{array}{c}\mathrm{K} \\
(\mathrm{mEq} / \mathrm{L})\end{array}$ & $4.94 \pm 1.15$ & $4.90 \pm 0.82$ & $5.24 \pm 0.92$ & $5.13 \pm 0.89$ \\
\hline
\end{tabular}

Data presented as mean \pm SD, Group I- EHT, Group 2 -T2DM, Group 3-EHT+T2DM and Group 4-Control subjects, $*$ P value $<0.05$ vs. Group 4 
subjects in the patient groups were significantly different from control subjects $(\mathrm{p}<0.05)$ for BMI. Elevated serum triglycerides strongly indicate the presence of metabolic syndrome in patients with T2DM [37]. Only in type 2 diabetic patients, the concentration of LDL-C was significantly different from control subjects and the type 2 diabetic subjects are at borderline high category $(>3.36$ $\mathrm{mmol} / \mathrm{l}$ ) according to NCEP ATPIII [38]. There was no significant difference found in LDL in hypertensive subjects with or without diabetes as compared to control group ( $\mathrm{p}$ $>0.05$ ). Triglycerides was significantly differed only in diabetic subjects $(\mathrm{p}<0.05)$ but not in other groups. Total cholesterol was not significantly differed between the patient groups and the control subjects as they found under desirable category according to NCEP ATPIII. The aggregation of risk factors found in our study was another determinant of the early occurrence of the disease. An elevation in TG, and a reduction in HDL-C favored the hypothesis that metabolic syndrome participates in the development of early CAD [39].

\section{Genotyping results}

Genetic polymorphisms involved in RAAS genes susceptibility to EHT and T2DM have been intensively scrutinized by linkage and association studies in various populations. The genes coding for each protein involved in the RAAS have been identified and studied for any relation with hypertension and other cardiovascular disorders [3,5]. Among the candidate genes of RAAS, AGT gene was considered as an important in the pathogenesis of EHT, since angiotensin II, a potent vasoconstrictor and a stimulator for aldosterone release which is obtained from the precursor molecule angiotensinogen by the proteolysis activity of renin and angiotensin converting enzyme [40]. Table 3 shows the genotypic and allelic frequency of RAAS gene polymorphisms in the subjects along with odds ratio and 95\% confidence interval. There was significant association found only in A6G variant of AGT gene in Malaysian EHT with or without T2DM subjects. Figures 1, 2, 3, 4, 5 shows the genotypes of RAAS gene polymorphisms separated in gel electrophoresis.

G allele of A6G variant shows nearly 90.91\% among the case subjects as compared to $9.09 \%$ of control subjects. The frequency was higher than those reported in whites but similar to that found in Japanese populations, suggesting that the A26G variant shows a significant ethnic difference $[41,28]$. Moreover, A6G variant found significantly associated with group 3 subjects when compared with control subjects (P-0.003) and was well accordance with Chilean Hispanic hypertensive subjects [42]. However, the results were also in contrast to few studies done in BMI subjects in Spanish population [43] and essential hypertensive subjects in Han, Tibetan and Yi populations [44] $(\mathrm{p}>0.05)$. A previous report [33] suggested that
M235T variant of AGT gene was well associated with Malaysian essential hypertensive patients. It has been well supported with the results of this study which shows that, AGT gene variants plays an important role in the pathogenesis of EHT. Tests of promoter activity and DNA interactions with factors involved in transcription initiation influence the basal rate of transcription of the gene [41]. These observations provide some biological insight about the possible mechanism by which individual differences in the AGT gene may predispose to EHT.

There was no significant association in relation to genotype or allele distributions of A20C variant of AGT gene found between the patients and the control subjects. CC genotype of A20C variant shows very less percentage $(2.05 \%)$ among the case subjects as compared to $1.33 \%$ of control subjects. The results of this study were well in accordance with the previous studies done in EHT patients from a Tibetan population [8] Japanese population [10].

Based on linkage and sib-pair linkage analysis and association studies, the effects of genetic variations in the REN gene have been studied extensively in human population. The results of various sib-pair analyses have been unsuccessful in clearly implicating REN gene variations as the etiological basis of hypertension [45]. MboI RFLP [30] is located in intron 9 and is probably not a functional genetic variation but shown strongly positive association with hypertension in different population groups. However, a study [46] shows that genetic variations in linkage disequilibrium with this site or in a nearby gene in linkage disequilibrium may be directly implicated in an individual's genetic susceptibility to blood pressure dysregulation. In support to that, another study shows that MboI polymorphism was susceptibility to EHT in UAE population [30]. In contrast to those studies, our study shows that the genotypes and alleles of MboI polymorphism of REN gene was not statistically significant difference between the cases and control subjects $(\mathrm{p}>0.05)$. The MboI (+) allele frequency in Malaysian hypertensive $(18.57 \%)$ and normotensive $(13.33 \%)$ subjects was lower than that in UAE population $51 \%$ and $36 \%$, respectively, $20 \%$ and $24 \%$ observed in normotensive subjects in North American and Japanese population respectively. The findings of MboI polymorphism of REN gene of this study was similar to the few studies which failed to show an association between hypertensive and normotensive subjects [47].

Several studies supported that, the variant in adducin gene in rats affects renal function by modulating the overall capacity of tubular epithelial cells to transport ions modifying the assembly of the actin cytoskeleton [48]. Few studies revealed that, the possible association of Trp allele 
Table 3: Genotypic and allelic distributions of RAAS gene polymorphisms

\begin{tabular}{|c|c|c|c|c|}
\hline Genotypes and Alleles & $\begin{array}{c}\text { Group I } \\
\text { n (\%) }\end{array}$ & $\begin{array}{c}\text { Group } 2 \\
\text { n (\%) }\end{array}$ & $\begin{array}{c}\text { Group } 3 \\
\text { n (\%) }\end{array}$ & $\begin{array}{c}\text { Group } 4 \\
\text { n (\%) }\end{array}$ \\
\hline $\begin{array}{l}\text { A6G Genotypes } \\
\text { AA }\end{array}$ & $43(6 I .43)$ & $50(83.30)$ & $40(61.54)$ & $68(90.67)$ \\
\hline AG & $20(28.57)$ & $7(11.70)$ & $17(26.15)$ & $6(8.00)$ \\
\hline GG & $7(10.00)$ & $3(5.00)$ & $8(|2.3|)$ & $\mathrm{I}(1.33)$ \\
\hline $\begin{array}{l}\text { A6G Alleles } \\
\text { C }\end{array}$ & $106(75.7 I)$ & $107(89.17)$ & $97(74.62)$ & $142(94.67)$ \\
\hline $\mathrm{T}$ & $34(24.29)$ & $13(10.83)$ & $33(25.38)$ & $8(5.33)$ \\
\hline $\begin{array}{c}\mathrm{P} \text { value } \\
\text { Odds ratio }(95 \% \mathrm{Cl})\end{array}$ & $\begin{array}{c}<0.00 I^{*} \\
1.76(0.08-0.39)\end{array}$ & $\begin{array}{c}0.112 \\
0.46(0.19-1.16)\end{array}$ & $\begin{array}{c}<0.00 I^{*} \\
1.66(0.07-0.37)\end{array}$ & - \\
\hline $\begin{array}{c}\text { A20C Genotypes } \\
\text { AA }\end{array}$ & $46(65.70)$ & $37(6 \mid .7)$ & $45(69.23)$ & $53(70.67)$ \\
\hline $\mathrm{AC}$ & $21(30.00)$ & $22(36.7)$ & $19(29.23)$ & $21(28.00)$ \\
\hline $\mathrm{CC}$ & $3(4.30)$ & I (I.6) & I (I.54) & I (I.33) \\
\hline $\begin{array}{c}\text { A20C Alleles } \\
\text { A }\end{array}$ & $113(80.70)$ & $96(80.00)$ & $109(83.80)$ & $127(84.67)$ \\
\hline $\mathrm{C}$ & $27(19.30)$ & $24(20.00)$ & $21(16.20)$ & $23(15.33)$ \\
\hline $\begin{array}{c}\mathrm{P} \text { value } \\
\text { Odds ratio }(95 \% \mathrm{Cl})\end{array}$ & $\begin{array}{c}0.437 \\
0.76(0.41-1.40)\end{array}$ & $\begin{array}{c}0.336 \\
0.72(0.39-1.36)\end{array}$ & $\begin{array}{c}0.87 \mid \\
0.94(0.49-|.7|)\end{array}$ & - \\
\hline $\begin{array}{c}\text { Mbol Genotypes } \\
(-/-)\end{array}$ & 46 (65.7I) & $43(71.67)$ & $47(72.3 \mathrm{I})$ & $56(74.67)$ \\
\hline$(-/+)$ & $22(31.43)$ & $16(26.67)$ & $15(23.08)$ & $18(24.00)$ \\
\hline$(+/+)$ & $2(2.86)$ & I (I.67) & $3(4.62)$ & $\mathrm{I}(1.33)$ \\
\hline $\begin{array}{c}\text { Mbol Alleles } \\
(-)\end{array}$ & $114(81.43)$ & $102(85.00)$ & $109(83.85)$ & $130(86.67)$ \\
\hline$(+)$ & $26(18.57)$ & $18(15.00)$ & $21(16.15)$ & $20(13.33)$ \\
\hline $\begin{array}{c}\mathrm{P} \text { value } \\
\text { Odds ratio }(95 \% \mathrm{Cl})\end{array}$ & $\begin{array}{l}0.261 \\
0.67(0.36-1.27)\end{array}$ & $\begin{array}{l}0.727 \\
0.87(0.44-1.73)\end{array}$ & $\begin{array}{l}0.612 \\
0.80(0.4|-| .55)\end{array}$ & \\
\hline $\begin{array}{c}\text { Lys I73Arg Genotypes } \\
\text { Lys } 173 / \text { Lys }\end{array}$ & $37(52.86)$ & $22(36.66)$ & $34(52.31)$ & $37(49.33)$ \\
\hline Lys 173/Arg & $31(44.28)$ & $37(61.67)$ & $30(46.15)$ & $37(49.33)$ \\
\hline Arg173/Arg & $2(2.86)$ & I (I.67) & I (I.54) & I (I.34) \\
\hline $\begin{array}{c}\text { Lys I73Arg Alleles } \\
\text { Lys }{ }^{173}\end{array}$ & $105(75.00)$ & $81(67.50)$ & $98(75.38)$ & III (74.00) \\
\hline Arg ${ }^{173}$ & $35(25.00)$ & $39(32.50)$ & $32(24.62)$ & $39(26.00)$ \\
\hline $\begin{array}{c}\mathrm{P} \text { value } \\
\text { Odds ratio }(95 \% \mathrm{Cl})\end{array}$ & $\begin{array}{l}0.893 \\
1.05(0.62-1.79)\end{array}$ & $\begin{array}{l}0.280 \\
0.73(0.43-1.24)\end{array}$ & $\begin{array}{c}0.89 \mid \\
1.08(0.63-1.85)\end{array}$ & - \\
\hline $\begin{array}{l}\text { Gly460Trp Genotypes } \\
\text { Gly } 460 / G l y\end{array}$ & $36(51.43)$ & $28(46.67)$ & $26(40.00)$ & $40(53.33)$ \\
\hline Gly460/Trp & $13(18.57)$ & $21(35.00)$ & $17(26.15)$ & $21(28.00)$ \\
\hline Trp $460 / T r p$ & $21(30.00)$ & II (I8.33) & $22(33.85)$ & $14(18.67)$ \\
\hline $\begin{array}{l}\text { Gly460Trp Alleles } \\
\text { Gly } 460\end{array}$ & 85 (60.7I) & 77 (64.17) & $69(53.08)$ & $96(64.00)$ \\
\hline $\operatorname{Trp}{ }^{460}$ & 55 (39.29) & $43(35.83)$ & $61(46.92)$ & $54(36.00)$ \\
\hline $\begin{array}{c}\mathrm{P} \text { value } \\
\text { Odds ratio }(95 \% \mathrm{Cl})\end{array}$ & $\begin{array}{c}0.564 \\
0.87(0.54-1.40)\end{array}$ & $\begin{array}{c}1.000 \\
1.01(0.61-1.66)\end{array}$ & $\begin{array}{c}0.064 \\
0.63(0.39-1.03)\end{array}$ & - \\
\hline
\end{tabular}

Data are reported as number of subjects with percent in parentheses, Group I- EHT, Group 2 -T2DM, Group 3- EHT+T2DM and Group 4Control subjects, ${ }^{*} P$ value $<0.001$ vs. Group 4 . 


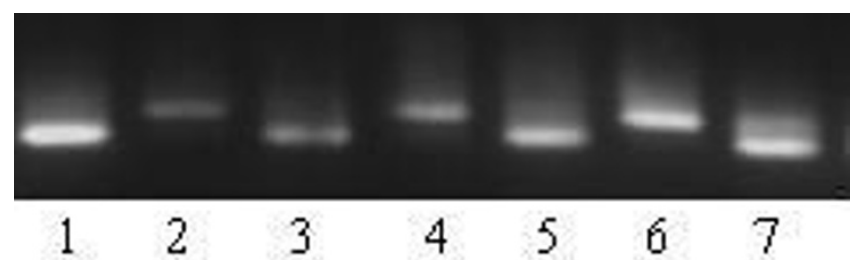

Figure I

Agarose gel electrophoresis showing the genotypes of RAAS gene polymorphisms. Llane I, 3 and 5 represents homozygous AA genotypes, lane 2, 4 and 6 represents homozygous GG genotypes and lane 7 shows the heterozygous AG genotypes of A6G polymorphism of AGT gene.

of Gly460Trp polymorphism of ADD1 was associated with an increased risk of EHT and T2DM [20]. In the present study, we could not detect any association of Trp allele of Gly460Trp polymorphism of ADD1 in Malaysian EHT with or without T2DM subjects. No association was found between the Gly460Trp allele and hypertension in Japanese population [29].

In relation with $\mathrm{T} 2 \mathrm{DM}$ the genotypes and alleles of Gly460Trp polymorphism shows no significant difference with control subjects $(P=1.000)$ which is similar to study done in Irish population [49] in relation with diabetic nephropathy and Type 1 diabetes $(P=0.087)$. However, there are still remains the possibility of ADD1 gene affects membrane ion transport because we did not investigate the effect on salt-sensitivity or response to diuretic treatment. However, several studies suggest that a variant in ADD1 gene on its own is insufficient to develop hypertension $[19,20]$.

The three common polymorphic variants of CYP11B2; C$344 \mathrm{~T}$ at 5 ' distal promoter region of the gene, a mutation in intron 2, and K173R (Lys173Arg) in exon 3 have been extensively evaluated in relation to hypertension and car-

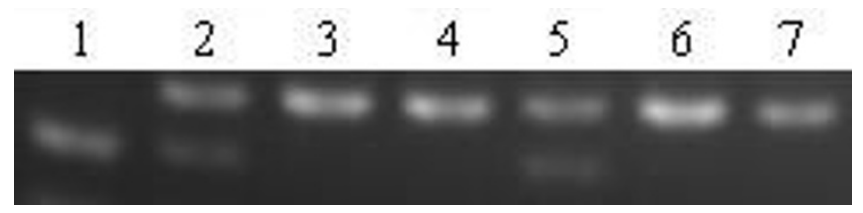

Figure 2

lane I represents homozygous CC genotypes, lane 2 and 5 represents heterozygous $A C$ genotypes and lane 3, 4, 6, and 7 represents homozygous AA genotypes of A20C polymorphism of AGT gene.

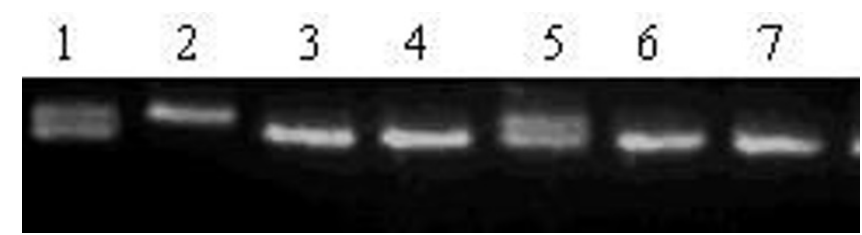

\section{Figure 3}

Lane I and 5 represents heterozygous Gly/Trp genotypes, lane 2 represents homozygous Gly/Gly genotypes, lane 3, 4, 6 and 7 represents homozygous Trp/ Trp genotypes of Gly460Trp polymorphism of alphaadducin gene.

diovascular disease. Unpublished data shows that, C344T variant of CYP11B2 is not associated with hypertension in Malays; an ethnic population in Malaysia. Hence, this study focus on the other variant Lys173Arg of CYP11B2 gene located at exon 3 which has been associated with low renin hypertensive patients in Chilean populations [42]. In this study, the frequency of the variant $A$ allele of Lys173Arg polymorphism was seen very less in hypertensive patients with T2DM $(24.62 \%)$ as compared to control subjects $(26.00 \%)$. No difference in AA genotype frequency was evident between hypertensive patients $(2.86 \%)$ and control subjects $(1.34 \%)$. Our results were totally diverged from the previous report [42] shows that Arg 173 allele frequency (21\%) in low renin hypertensive Chilean subjects.

Table 4 shows the genotypic and allelic distributions of RAAS gene polymorphisms between male and female sub-

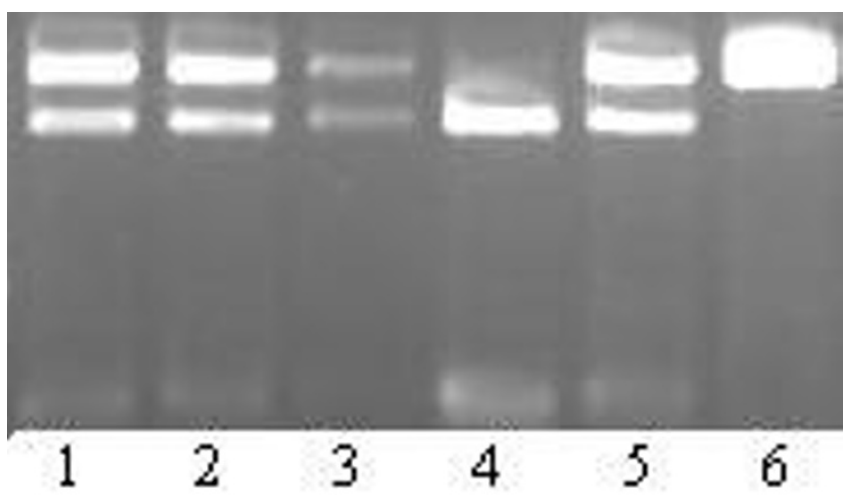

Figure 4

Lane I, 2, 3 and 5 represents heterozygous Lys/Arg genotypes, lane 4 represents homozygous Lys/Lys genotypes and lane 6 represents homozygous Arg/ Arg genotypes of Lys I 73Arg polymorphism of aldosterone synthase gene. 


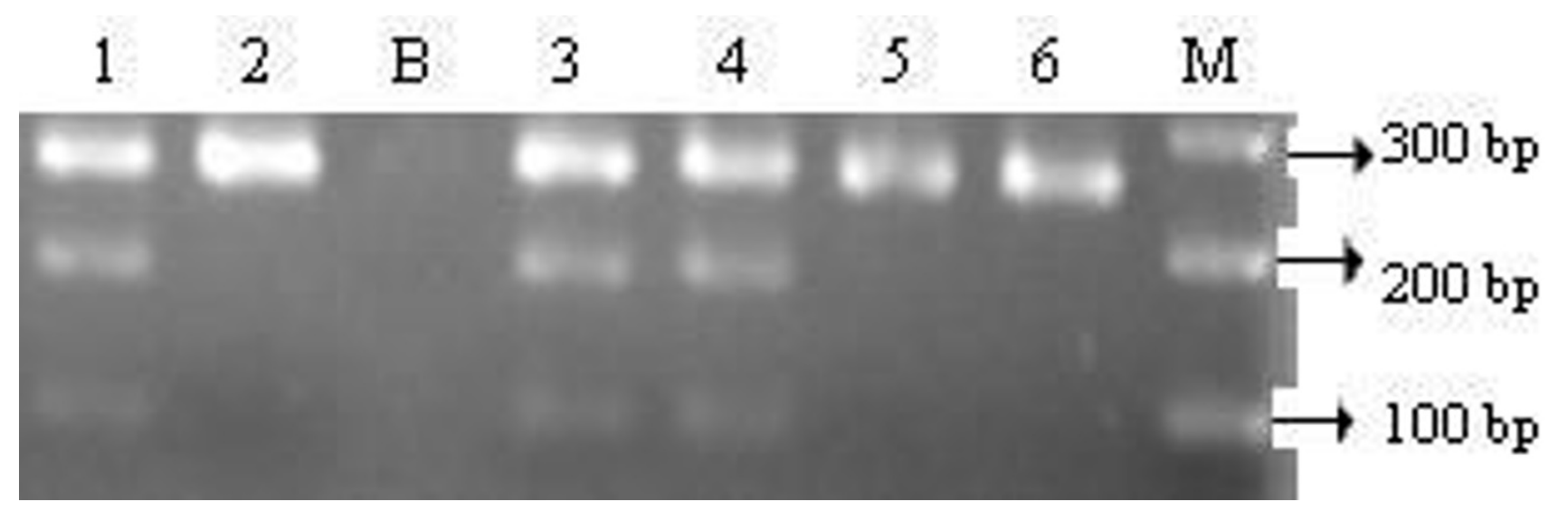

Figure 5

Lane I, 3 and 4 represents heterozygous +/- genotypes and lane 2, 5 and 6 represents homozygous -/- genotypes of $\mathrm{Mbol}$ polymorphism of renin gene. $M$ represents $100 \mathrm{bp}$ ladder and $\mathrm{B}$ represents the negative control without the template DNA.

jects. There was no significant difference was found in either genotypic or allelic distribution in both male and female subjects ( $\mathrm{p}>0.05$ ).

Some evidence shows that modulation of the RAAS by use of angiotensin-converting enzyme inhibitors or angiotensn II receptor blockers leads to improved insulin sensitivity, glycemic control and possibly prevention of T2DM [50]. This study failed to show significant association between all the five genetic polymorphisms of RAAS genes with T2DM. The reason might be the different methods used or may occur due to racial differences or heterogeneity of the population sampling bias or possibly due to the environmental factors may contribute to the negative associations [51]. Moreover, despite the considerable controversy regarding the existence and importance of ethnic differences in genetic effects for complex diseases, it seems evident that genetic markers for proposed gene-disease associations vary in frequency across populations. Association studies must be repeated in this population to ensure that any association of candidate genes with T2DM is pathogenetically significant.

\section{Study limitations}

The present study has to be interpreted within the context of its limitations. The present study provided only the evidences of the association between the genetic polymorphisms of RAAS genes with EHT and T2DM at the gene level and we did not address the mechanism or the functionality of the variants. The control subjects are not age, sex matched and they are relatively young as compared to case subjects. Further association/replication studies with well-designed larger sample size subjects involving other polymorphisms of RAAS genes in related to cardiovascular diseases is recommended.

\section{Conclusion}

Among the five polymorphisms of RAAS genes, only A6G variant of AGT gene was significantly associated in EHT with or without T2DM, other polymorphisms were failed to show any significant association between the case and control subjects. In conclusion, the present study implies that genotyping for the A6G variant of AGT gene could in the future become an important part of the clinical process of risk identification for EHT and T2DM in Malaysian population.

\section{Abbreviations \\ AGT: Angiotensinogen; BMI: Body mass index; CAD: Cor- onary artery disease; EHT: Essential hypertension; DBP: Diastolic Blood Pressure; FPG: Fasting plasma glucose level; HDL-C: High density lipoprotein cholesterol; K: Potassium; LDL-C: Low density lipoprotein cholesterol; Na: Sodium; PCR: Polymerase chain reaction; RAAS: Renin Angiotensin Aldosterone System; REN: Renin; RFLP: Restriction fragment length polymorphism; T2DM: Type 2 Diabetes Mellitus; SBP: Systolic blood pressure; TG: Triglycerides and TC: Total cholesterol.}

\section{Competing interests}

The authors declare that they have no competing interests.

\section{Authors' contributions}

$\mathrm{RV}$ and PI conceived the study and RV participated in the experimental design, data acquisition and analysis, interpretation of results, and drafted the manuscript. PI, JS and 
Table 4: Allelic distribution of RAAS gene polymorphisms in gender

\begin{tabular}{|c|c|c|c|c|c|c|c|c|c|}
\hline \multirow[b]{2}{*}{$\begin{array}{l}\text { Alleles of RAAS Gene } \\
\text { Polymorphisms }\end{array}$} & & \multicolumn{2}{|c|}{ Group I } & \multicolumn{2}{|c|}{ Group 2} & \multicolumn{2}{|c|}{ Group 3} & \multicolumn{2}{|c|}{ Group 4} \\
\hline & & Male & Female & Male & Female & Male & Female & Male & Female \\
\hline \multirow[t]{2}{*}{$\mathrm{A} 6 \mathrm{G}$} & C & $\begin{array}{c}76 \\
(78.40)\end{array}$ & $\begin{array}{c}26 \\
(21.60)\end{array}$ & $\begin{array}{c}60 \\
(90.90)\end{array}$ & $\begin{array}{c}6 \\
(9.10)\end{array}$ & $\begin{array}{c}61 \\
(76.25)\end{array}$ & $\begin{array}{c}19 \\
(23.75)\end{array}$ & $\begin{array}{c}74 \\
(94.87)\end{array}$ & $\begin{array}{c}4 \\
(5.13)\end{array}$ \\
\hline & $\mathrm{T}$ & $\begin{array}{c}30 \\
(89.50)\end{array}$ & $\begin{array}{c}8 \\
(10.50)\end{array}$ & $\begin{array}{c}47 \\
(87.04)\end{array}$ & $\begin{array}{c}7 \\
(12.96)\end{array}$ & $\begin{array}{c}36 \\
(65.45)\end{array}$ & $\begin{array}{c}14 \\
(25.45)\end{array}$ & $\begin{array}{c}68 \\
(94.44)\end{array}$ & $\begin{array}{c}4 \\
5.56)\end{array}$ \\
\hline \multicolumn{2}{|l|}{$\begin{array}{c}\text { P value } \\
\text { OR }(95 \% \mathrm{Cl})\end{array}$} & \multicolumn{2}{|c|}{$\begin{array}{c}0.662 \\
0.78(0.318-1.914)\end{array}$} & \multicolumn{2}{|c|}{$\begin{array}{c}0.563 \\
1.49(0.469-4.729)\end{array}$} & \multicolumn{2}{|c|}{$\begin{array}{c}0.680 \\
1.25(0.559-2.790)\end{array}$} & \multicolumn{2}{|c|}{$\begin{array}{c}1.000 \\
1.09(0.262-4.522)\end{array}$} \\
\hline \multirow[t]{2}{*}{$\mathrm{A} 20 \mathrm{C}$} & A & $\begin{array}{c}82 \\
(80.40)\end{array}$ & $\begin{array}{l}20 \\
(19.60)\end{array}$ & $\begin{array}{c}55 \\
(83.30)\end{array}$ & $\begin{array}{c}11 \\
(16.70)\end{array}$ & $\begin{array}{c}70 \\
(87.50)\end{array}$ & $\begin{array}{c}10 \\
(12.50)\end{array}$ & $\begin{array}{c}67 \\
(85.90)\end{array}$ & $\begin{array}{c}11 \\
(14.10)\end{array}$ \\
\hline & C & $\begin{array}{c}31 \\
(81.60)\end{array}$ & $\begin{array}{c}7 \\
(18.40)\end{array}$ & $\begin{array}{c}41 \\
(76.00)\end{array}$ & $\begin{array}{c}13 \\
(24.00)\end{array}$ & $\begin{array}{c}39 \\
(78.00)\end{array}$ & $\begin{array}{c}11 \\
(22.00)\end{array}$ & $\begin{array}{c}60 \\
(83.33)\end{array}$ & $\begin{array}{l}12 \\
(1.67)\end{array}$ \\
\hline \multicolumn{2}{|l|}{$\begin{array}{c}\text { P value } \\
\text { OR }(95 \% \mathrm{Cl})\end{array}$} & \multicolumn{2}{|c|}{$\begin{array}{c}1.000 \\
0.93(0.356-2.045)\end{array}$} & \multicolumn{2}{|c|}{$\begin{array}{c}0.363 \\
1.59(0.645-3.896)\end{array}$} & \multicolumn{2}{|c|}{$\begin{array}{c}0.220 \\
1.97(0.770-5.063)\end{array}$} & \multicolumn{2}{|c|}{$\begin{array}{c}0.82 \mathrm{I} \\
\mathrm{I} .22(0.50 \mathrm{I}-2.964)\end{array}$} \\
\hline \multirow[t]{2}{*}{ Mbol } & $(-)$ & $\begin{array}{c}85 \\
(83.33)\end{array}$ & $\begin{array}{c}17 \\
(16.67)\end{array}$ & $\begin{array}{c}58 \\
(87.88)\end{array}$ & $\begin{array}{c}8 \\
(12.12)\end{array}$ & $\begin{array}{c}66 \\
(82.50)\end{array}$ & $\begin{array}{c}14 \\
(17.50)\end{array}$ & $\begin{array}{c}65 \\
(83.33)\end{array}$ & $\begin{array}{c}13 \\
(16.67)\end{array}$ \\
\hline & $(+)$ & $\begin{array}{c}29 \\
(76.32)\end{array}$ & $\begin{array}{c}9 \\
(23.68)\end{array}$ & $\begin{array}{c}44 \\
(81.48)\end{array}$ & $\begin{array}{c}10 \\
(18.52)\end{array}$ & $\begin{array}{c}43 \\
(86.00)\end{array}$ & $\begin{array}{c}7 \\
(14.00)\end{array}$ & $\begin{array}{c}65 \\
(90.28)\end{array}$ & $\begin{array}{c}7 \\
(9.72)\end{array}$ \\
\hline \multicolumn{2}{|l|}{$\begin{array}{c}\mathrm{P} \text { value } \\
\text { OR }(95 \% \mathrm{Cl})\end{array}$} & \multicolumn{2}{|c|}{$\begin{array}{c}0.339 \\
1.55(0.624-3.860)\end{array}$} & \multicolumn{2}{|c|}{$\begin{array}{c}0.442 \\
1.65(0.601-4.519)\end{array}$} & \multicolumn{2}{|c|}{$\begin{array}{c}0.635 \\
0.77(0.287-2.056)\end{array}$} & \multicolumn{2}{|c|}{$\begin{array}{c}0.238 \\
0.54(0.202-1.436)\end{array}$} \\
\hline \multirow[t]{2}{*}{ Lys 173Arg } & Lys ${ }^{173}$ & $76(74.5 I)$ & $26(25.49)$ & $44(66.70)$ & $22(33.30)$ & $59(73.75)$ & $21(26.25)$ & $58(74.36)$ & $20(25.64)$ \\
\hline & Arg 173 & $29(76.30)$ & $\begin{array}{c}9 \\
(23.70)\end{array}$ & $37(68.52)$ & $17(31.48)$ & $39(78.00)$ & II (22.00) & $53(73.61)$ & $19(26.39)$ \\
\hline \multicolumn{2}{|l|}{$\begin{array}{c}\text { P value } \\
\text { OR }(95 \% \mathrm{Cl})\end{array}$} & \multicolumn{2}{|c|}{$\begin{array}{c}1.000 \\
0.90(0.380-2.166)\end{array}$} & \multicolumn{2}{|c|}{$\begin{array}{c}0.847 \\
0.92(0.426-1.983)\end{array}$} & \multicolumn{2}{|c|}{$\begin{array}{c}0.678 \\
0.79(0.344-1.825)\end{array}$} & \multicolumn{2}{|c|}{$\begin{array}{c}1.000 \\
1.04(0.501-2.157)\end{array}$} \\
\hline \multirow[t]{2}{*}{ Gly460Trp } & Gly460 & $\begin{array}{c}66 \\
(64.71)\end{array}$ & $\begin{array}{c}36 \\
(35.29)\end{array}$ & $\begin{array}{c}42 \\
(63.64)\end{array}$ & $\begin{array}{c}24 \\
(36.36)\end{array}$ & $\begin{array}{c}46 \\
(57.50)\end{array}$ & $\begin{array}{c}34 \\
(42.50)\end{array}$ & $\begin{array}{c}52 \\
(69.30)\end{array}$ & $\begin{array}{c}26 \\
(30.70)\end{array}$ \\
\hline & $\operatorname{Trp}^{460}$ & $\begin{array}{c}19 \\
(50.00)\end{array}$ & $\begin{array}{c}19 \\
(50.00)\end{array}$ & $\begin{array}{c}35 \\
(64.81)\end{array}$ & $\begin{array}{c}19 \\
(35.19)\end{array}$ & $\begin{array}{c}23 \\
(46.00)\end{array}$ & $\begin{array}{c}27 \\
(54.00)\end{array}$ & $\begin{array}{c}44 \\
(61.11)\end{array}$ & $\begin{array}{c}28 \\
(38.89)\end{array}$ \\
\hline \multicolumn{2}{|l|}{$\begin{array}{c}\mathrm{P} \text { value } \\
\text { OR }(95 \% \mathrm{Cl})\end{array}$} & \multicolumn{2}{|c|}{$\begin{array}{c}0.124 \\
1.88(0.862-3.899)\end{array}$} & \multicolumn{2}{|c|}{$\begin{array}{c}0.893 \\
0.95(0.458-2.012)\end{array}$} & \multicolumn{2}{|c|}{$\begin{array}{c}0.201 \\
I .59(0.780-3.234)\end{array}$} & \multicolumn{2}{|c|}{$\begin{array}{c}0.479 \\
1.27(0.653-2.482)\end{array}$} \\
\hline
\end{tabular}

Data are reported as number of subjects with percent in parentheses, OR-odds ratio, Cl - Confidence interval, Group I- EHT, Group 2 -T2DM, Group 3- EHT+T2DM and Group 4-Control subjects, P value $>0.05$ vs. Group 4.

NS interpreted the results and critically reviewed the study for important intellectual content. All authors approved the final version of the manuscript.

\section{Acknowledgements}

This study was supported by the Ministry of Science, Technology and Environment (MOSTE), IRPA Project Grant No. 06-02-04-I0054-EAR. The authors would like to extend their gratitude to all the volunteers who involved in this study.

\section{References}

I. Corvol P, Soubrier F, Jeunemaitre X: Molecular genetics of the renin-angiotensin- aldosterone system in human hypertension. Pathol Biol 1997, 45:229-239.
2. Sameer NS, El-Atat FA, Sowers IR: Pathogenesis of Hypertension in Diabetes. Rev End Metab Dis 2004, 5:22I-225.

3. Zhu X, Chang YP, Yan D, Weder A, Cooper R, Luke A, Kan D, Chakravarti A: Associations between hypertension and genes in the renin-angiotensin system. Hypertension 2003, 41:1027-34.

4. van Ittersum FJ, de Man AM, Thijssen S, de Knijff P, Slagboom E, Smulders Y, Tarnow L, Donker AJ, Bilo HJ, Stehouwer CD: Genetic polymorphisms of the renin-angiotensin system and complications of insulin-dependent diabetes mellitus. Nephrol Dia Transplant 2000, 15:1000-1007.

5. Buraczynska M, Pijanowski Z, Spasiewicz D, Nowicka T, Sodolski T, Widomska-Czekajska T, Ksiazek A: Renin-angiotensin system gene polymorphisms: assessment of the risk of coronary heart disease. Kardiol Pol 2003, 58: I-9.

6. Buraczynska M, Ksiazek P, Drop A, Zaluska W, Spasiewicz D, Ksiazek A: Genetic polymorphisms of the renin-angiotensin system in end-stage renal disease. Nephrol Dial Transplant 2006, 21:979-983. 
7. Jeunemaitre $X$, Soubrier F, Kotelevtsev $Y V$, Lifton RP, Williams CS, Charru A, Hunt SC, Hopkins PN, Williams RR, Lalouel JM: Molecular basis of human hypertension: role of angiotensinogen. Cell 1992, 71:169-180.

8. Niu W, Qi Y, Cen W, Cui C, Zhuoma C, Cai D, Zhou W, Qiu C: Genetic polymorphisms of angiotensinogen and essentia hypertension in a Tibetan population. Hypertens Res 2007, 30: II29-I I37

9. Chang HR, Cheng $\mathrm{CH}$, Shu $\mathrm{KH}$, Chen $\mathrm{CH}$, Lian JD, Wu MY: Study of the polymorphism of angiotensinogen, anigiotensin-converting enzyme and angiotensin receptor in type II diabetes with end-stage renal disease in Taiwan. J Chin Med Assoc 2003 , 66:5I-56.

10. Ishigami T, Umemura S, Tamura K, Hibi K, Nyui N, Kihara M, Yabana M, Watanabe Y, Sumida Y, Nagahara T, Ochiai H, Ishii M: Essential hypertension and $5_{-}$upstream core promoter region of human angiotensinogen gene. Hypertension 1997, 30:1325-1330.

II. Inoue I, Nakajima T, Williams CS, Quackenbush J, Puryear R, Powers M, Cheng T, Ludwig EH, Sharma AM, Hata A, Jeunemaitre X, Lalouel JM: A nucleotide substitution in the promoter of human angiotensinogen is associated with essential hypertension and affects basal transcription in vitro. J Clin Invest 1997, 99: $1786-1797$.

12. Chiang FT, Hsu KL, Tseng CD, Lo HM, Chern TH, Tseng YZ: Association of the renin gene polymorphism with essential hypertension in a Chinese population. Clin Genet 1997, 5 I:370-374.

13. Frossard PM, Kane JP, Malloy MJ, Bener A: Renin gene Mbol dimorphism is a discriminator for hypertension in hyperlipidaemic subjects. Hypertens Res 1999, 22:285-289.

14. Fu Y, Katsuya T, Asai T, Fukuda M, Inamoto N, Iwashima Y, Sugimoto $\mathrm{K}$, Rakugi H, Higaki J, Ogihara $\mathrm{T}$ : Lack of correlation between Mbo I restriction fragment length polymorphism of rennin gene and essential hypertension in Japanese. Hypertens Res 200I, 24:295-298.

15. White PC: Disorders of aldosterone biosynthesis and action. New Engl J Med 1994, 33 I:250-258.

16. Curnow KM, Tusie-Luna MT, Pascoe L, Natarajan R, Gu JL, Nadler JL, White PC: The product of the CYPI IB2 gene is required for aldosterone biosynthesis in the human adrenal cortex. Mol Endocrinol 1991, 5:1513-1522.

17. While PC, Slutsker L: Haplotypes analysis of CYPI IB2. Endocrinol Res 1995, $21: 437-442$.

18. Komiya I, Yamada T, Takara M, Asawa T, Shimabukuro M, Nishimori T, Takasu N: Lys( I 73)Arg and -344T/C variants of CYP I I B2 in Japanese patients with low-renin hypertension. Hypertension 2000, 35:699-703.

19. Staessen JA, Bianchi G: Adducin and hypertension. Pharmacogenomics 2005, 7:665-669.

20. Cusi D, Barlassani C, Azzani T, Casari G, Citterio L, Devoto M, Glorioso N, Lanzani C, Manunta $P$, Righetti $M$, Rivera $R$, Stella $P$, Troffa C, Zagato L, Bianchi G: Polymorphisms of alpha-adducin and salt sensitivity in patients with essential hypertension. Lancet 1997, 349:1353-1357.

21. Klein R, Klein BE, Lee KE, Cruickshanks KJ, Moss SE: The incidence of hypertension in insulin-dependent diabetes. Arch Inter Med 1996, I 56:622-627.

22. Govindarajan G, Whaley-Connell A, Mugo M, Stump C, Sowers JR: The cardiometabolic syndrome as a cardiovascular risk factor. Am J Med Sci 2005, 330:3 I I-3 I8.

23. Miller JA, Floras JS, Zinman B, et al.: Effect of hyperglycaemia on arterial pressure, plasma rennin activity and renal function in early diabetes. Clin Sci 1996, 90:189-195.

24. Marre M, Jeunemaitre X, Gallois $Y$, Rodier M, Chatellier G, Sert C, Dusselier L, Kahal Z, Chaillous L, Halimi S, Muller A, Sackmann H, Bauduceau B, Bled F, Passa P, Alhenc-Gelas F: Contribution of genetic polymorphism in the renin- angiotensin system to the development of renal complications in insulin-. dependent diabetes: Genetique de la Nephropathie Diabetique (GENEDIAB) study group. J Clin Invest 1997, 99:I585-1595.

25. Agarwal A, Williams GH, Fisher ND: Genetics of human hypertension. Trends Endocrinol Metab 2005, 16:127-133.

26. Friedewald WT, Levy RI, Fredrickson DS: Estimation of low density lipoprotein cholesterol without the use of the preparative ultracentrifuge. Clin Chem 1972, 18:499-502.
27. Rust S, Funke H, Assmann G: Mutagenically separated PCR (MSPCR): a highly specific one step procedure for easy mutation detection. Nucl Acids Res 1993, 21:3623-3629.

28. Jeunemaitre $X$, Inoue I, Williams C, Charru A, Tichet J, Powers $M$, Sharma AM, Gimenez-Roqueplo AP, Hata A, Corvol P, Lalouel JM: Haplotypes of angiotensinogen in essential hypertension. Am J Hum Genet 1997, 60: |448-1460.

29. Kato N, Sugiyama T, Nabika T, Morita H, Kurihara H, Yazaki Y, Yamori $Y$ : Lack of association between the alpha-adducin locus and essential hypertension in the Japanese population. Hypertension 1998, 31:730-733.

30. Frossard PM, Lestringant GG, Elshahat YI, John A, Obineche EN: An Mbol two-allele polymorphism may implicate the human renin gene in primary hypertension. Hypertens Res 1998, 2I:22I-225

31. Tamaki S, Iwai N, Tsujita Y, Kinoshita M: Genetic polymorphism of CYP I I B2 gene and hypertension in Japanese. Hypertension 1999, 33:266-270.

32. Morton NE, Collins A: Tests and estimates of allelic association in complex inheritance. PNAS 1998, 95: I I389- I I393.

33. Say $\mathrm{YH}$, Ling KH, Duraisamy G, Isaac S, Rosli R: Angiotensinogen M235T gene variants and its association with essential hypertension and plasma renin activity in Malaysian subjects: a case control study. BMC Cardiovas Dis 2005, 5:7.

34. Ghazali DM, Rehman A, Rahman AR: Candidate gene polymorphisms and their association with hypertension in Malays. Clin Chim Acta 2008, 388:46-50.

35. Rampal L, Rampal S, Azharc MZ, Rahmand AR: Prevalence, awareness, treatment and control of hypertension in Malaysia: A national study of 16,440 subjects. Pub Health 2007, I 22: I I- I8.

36. Chobanian AV, Bakris GL, Black HR: The seventh report of the joint national committee on prevention, detection, evaluation and treatment of high blood pressure. Hypertension 2003:1206-1252.

37. Kompoti M, Mariolis A, Alevizos A, Kyriazis I, Protopsaltis I, Dimou E, Lentzas I, Levisianou D, Gova A, Melidonis A: Elevated serum triglycerides is the strongest single indicator for the presence of metabolic syndrome in patients with type 2 diabetes. Cardiovasc Diabetol 2006, 5:21.

38. Expert panel on detection, evaluation, and treatment of high blood cholesterol in adults. Executive summary of the third report of the National Cholesterol Education Program (NCEP) expert panel on detection, evaluation, and treatment of high blood cholesterol in adults (Adult Treatment Panel III). JAMA 200I, 285:2486-2497.

39. Thomas GN, Tomlinson B, Chan JC, Lee ZS, Cockran CS, Critchley $\mathrm{A}$ : An insulin receptor gene polymorphism is associated with diastolic blood pressure in Chinese subjects with components of the metabolic syndrome. Am J Hypertens 2000, I 3:745-752.

40. Davis GK, Roberts DH: Molecular genetics of the renin-angiotensin system: Implications for angiotensin II receptor blockage. Pharmacol Ther 1997, 75:43-50.

4I. Inoue I, Nakajima T, Williams CS, Quackenbush J, Puryear R, Powers M, Cheng T, Ludwig EH, Sharma AM, Hata A, Jeunemaitre X, Lalouel JM: A nucleotide substitution in the promoter of human angiotensinogen is associated with essential hypertension and affects basal transcription in vitro. $\int \mathrm{C}$ Invest 1997. 99: I 786- I797.

42. Fardella CE, Rodriguez $\mathrm{H}$, Montero J, Zhang G, Vignolo P, Rojas A, Villarroel L, Miller WL: Genetic variation in P450 c I AS in Chilean patients with low renin hypertension. J Clin Endocrinol Metab 1996, 8 I:4347-435I.

43. Chaves FJ, Giner V, Corella D, Pascual J, Marin P, Armengod ME, Redon J: Body weight changes and the A-6G polymorphism of the angiotensinogen gene. Inter J Obes Relat Metab Disord 2002, 26: I173-1178.

44. Liu Y, Qin W, Hou S, Shan G, Zhuo M, Chen Y, Cui C, Caidan L, Qiu $C$ : A-6G variant of the angiotensinogen gene and essential hypertension in Han, Tibetan, and Yi populations. Hypertens Res 200I, 24:159-163.

45. Jeunemaitre X, Rigat B, Charru A, Houot AM, Soubrier F, Corvol P: Sib pair linkage analysis of renin gene haplotypes in human hypertension. Hum Genet 1992, 88:301-306.

46. Okura T, Kitami Y, Hiwada K: Restriction fragment length polymorphisms of the human renin gene: association study with 
a family history of essential hypertension. J Hum Hypertens 1993, 7:457-461.

47. Berg KE, Berg K: No effect of a Bgll polymorphism at the renin (REN) locus on blood pre s s ure level or variability. Clin Genet 1994, 46:436-438.

48. Cusi $D$, Bianchi G: Renal mechanisms of genetic hypertension: from the molecular level to the intact organism. Kid Inter 1996, 49: 1754-1759.

49. Conway BR, Martin R, McKnight A, Savage DA, Brady HR, Maxwell AP: Role of a-adducin DNA polymorphisms in the genetic predisposition to diabetic nephropathy. Nephrol Dial Transpl 2004, 19:2019-2024.

50. Jennifer MP, Stephen ND: The renin-angiotensin-aldosterone system: a pivotal role in insulin sensitivity and glycemic control. Curr Opin Endocrinol Diabetes Obes 2008, 15:147-152.

51. Persu A: Candidate gene studies: accepting negative results. J Hypertens 2006, 24:443-445.

Publish with Bio Med Central and every scientist can read your work free of charge

"BioMed Central will be the most significant development for disseminating the results of biomedical research in our lifetime. "

Sir Paul Nurse, Cancer Research UK

Your research papers will be:

- available free of charge to the entire biomedical community

- peer reviewed and published immediately upon acceptance

- cited in PubMed and archived on PubMed Central

- yours - you keep the copyright

Submit your manuscript here:

http://www.biomedcentral.com/info/publishing_adv.asp
BiolMedcentral 